\title{
Electrochemical assessment of some titanium and stainless steel implant
}

\section{dental alloys}

\author{
A. Echavarría* and C. Arroyave*
}

\begin{abstract}
Commercially pure titanium alloy, Ti-6Al-4V alloy and stainless steel screw implants were evaluated in both Ringer and synthetic saliva physiological solutions at body temperature by EIS (Electrochemical Impedance Spectroscopy) with immersion times of 30 d. Results were simulated as a "sandwich system" composed by four capacitors-resistances connected in series with the solution resistance. A model explaining the results in terms of the porosity and thickness of four different layers, was proposed.
\end{abstract}

Keywords Dental alloys. Surgical stainless steel. Ringer's solution. Synthetic saliva solution. Electrochemical impedance spectroscopy.

\section{Evaluación electroquímica de algunas aleaciones para implantes dentales del tipo titanio y acero inoxidable}

Resumen

Palabras clave

\begin{abstract}
Se utilizó la técnica de la Espectroscopía de Impedancia Electroquímica para evaluar en soluciones fisiológicas artificiales (Ringer y saliva sintética) muestras extraídas de tornillos de implantes dentales certificados de titanio comercialmente puro, aleación $\mathrm{Ti}-6 \mathrm{Al}-4 \mathrm{~V}$ y acero inoxidable a temperatura corporal, con tiempos de inmersión hasta de $30 \mathrm{~d}$. Los resultados se simularon mediante un modelo del tipo sandwich de cuatro elementos RC, conectados en serie con una resistencia de la solución. A partir de de esta simulación, se propone un modelo que explica los resultados obtenidos en términos de la evolución de la porosidad y el espesor de cuatro diferentes capas que se desarrollan en la superficie de los materiales evaluados.
\end{abstract}

Aleaciones dentales. Acero inoxidable quirúrgico. Solución de Ringer. Solución de saliva sintética. Espectroscopía de impedancia electroquímica.

\section{INTRODUCTION}

Dental alloys are usually $\mathrm{Hg}$-based (amalgams), Tibased (commercially pure and Ti-6Al-4V), stainless steels (CrNiMo type), precious based (gold, silver, palladium, platinum and its combinations) or $\mathrm{Ni}-\mathrm{Ti}$ alloys ${ }^{[1-5]}$. It is a common practice in restorative surgery on edentolous patients the use of titanium and Ti-6Al-4V to support a complete denture prostheses, a terminal or intermediate abutment for fixed bridgework or partial dentures, or a single tooth replacement, overdenture or hybrid denture. These dental implants can be used in the mandible or maxilla in forms of screws and healing heads to complete the tissue healing process. Various sizes are available to fit in the sockets created in healed bone or into fresh extraction sites. Conversely, stainless steel $316 \mathrm{~L}$ is commonly employed in form of dental wire for restorative retentions and orthopaedic implants as femoral prostheses, compresion plates, screws and pins.

Various physiological synthetic fluids are used to simulate body, bucal, dentinal or bone conditions $^{[6-12]}$. It is normal to use Ringer, Hartmann, or Tyrode's solutions to simulate the synovial or intersticial fluids. All of them contain great amounts of chlorides, as it is typical of the dentinal fluids. Various synthetic saliva solutions includes the use of urea, lactic acid and tiocianate ions. In addition, it is common to use microoganisms to simulate the formation of biofilms or flourine ions to evaluate the effect of anticariogenic agents.

These alloys have been frequently assesed by means of the Electrochemical Impedance Spectroscopic technique - EIS ${ }^{[2,3,5,7,10 \text { and 11], }}$

(*) Corrosion and Protection Group, University of Antioquia, P.O. Box 1.226, Medellín, Colombia. 
Potenciodynamic Curves ${ }^{[1-4}$ and 6-12], Linear Polarization Resistance ${ }^{[2}$ and 3$]$, Potenciostatic or Galvanostatic curves and Electrochemical noise [1-4, 6-12 and 16]

The aim of the present study was to evaluate the behaviour of three implant alloys (commercially pure titanium, Ti 6Al 4V and stainless Steel 316L) in two physiological solutions (Ringer and saliva synthetic solutions) by employing the EIS technique.

\section{EXPERIMENTAL PROCEDURE}

The specimens of commercially pure titanium and $\mathrm{Ti} 6 \mathrm{Al} 4 \mathrm{~V}$ alloy from certificated, hexagonal top screw $3.75 \times 13 \mathrm{~mm}$, were extracted ${ }^{[12]}$. Furthermore, stainless steel specimens were extracted from certificated orthopaedic implant cortex screw of $4.5 \mathrm{~mm}$ diameter $\times 30 \mathrm{~mm}$ lenght. All the implants were machined, grinded and polished with $\mathrm{SiC} 1000$ mesh, to a nominal round cross section of c.a. $0.03 \mathrm{~cm}^{2}$, then diamond cut to a nominal lenght of $4 \mathrm{~mm}$. A $1 \mathrm{~mm}$ diameter copper rod was spot welded to the implant by capacitor discharge welding. Each assembly was mounted in phenolic metallographic resin (compressed to $5000 \mathrm{psi}$ for $12 \mathrm{~min}$ at $150^{\circ} \mathrm{C}$ ) of $25 \mathrm{~mm}$ diameter. Then, a 12 AWG TW insulated electrical wire of $150 \mathrm{~mm}$ lenght, was lead soldered to the copper rod in the phenolic paste. The above contact was protected from the test solution by cast epoxic resin in $25 \mathrm{~mm}$ diameter plastic molds. The surfaces of the specimens were prepared by classic metallographic techniques and polished with $\mathrm{SiC}$ 1000 mesh, washed in reagent grade acetone, and mounted in the cells with adhesive termoplastic silicone sealent.

The cells for EIS test were made in polimetilmetacrilate (PMMA) $3.75 \mathrm{~mm}$ acrilic plate, joined together with methylene chloride. All tests were performed in a one liter beaker capacity of solution. Spectroscopic type high purity graphite of $6 \mathrm{~mm}$ of diameter and $160 \mathrm{~mm}$ of lenght was used as auxiliar electrode. The surface area ratios of auxiliary and working electrode was 3000:1. The cells were designed in order to obtain a minimum of vibrations, which could distort the signals during the tests. Each capillary for the electrode (SCE) was epoxic joined at a fixed distance of the surfaces of the implants without interfering the electrical field. A pyrex tube of $2 \mathrm{~mm}$ inner diameter was inserted for inlet gas (nitrogen or air) to the solution. The data were taken with the same saturated calomel electrode, previously immersed in saturated $\mathrm{KCl}$ solution. The immersion times were up to one month.

The cells were immersed in a thermostatized bath and electromagnetic protected by means of a "Faraday Cell", clothed in aluminum paper, covered with a portable stainless steel mesh and earthed to computer terminals. The body temperature, $37^{\circ} \mathrm{C}$, was kept constant during testing, overnight and weekend days included, by pumping warm liquid of a 501 external tank, heated by a immersion heater controlled by an autotransformer. The temperature was taken with a digital thermocouple. All assembly was mounted in a wood table covered by aluminum paper and provided with an antivibratory system consisting of six tennis balls.

Two corrosive media were used. The solutions were prepared with distilled water and reagent grade materials. The Ringer's solution ${ }^{[12]}$ containing $8.60 \mathrm{~g} \cdot \mathrm{l}^{-1} \mathrm{NaCl}, 0.3 \mathrm{~g} \cdot \mathrm{l}^{-1} \mathrm{KCl}$ and $0.33 \mathrm{~g} \cdot \mathrm{l}^{-1}$ $\mathrm{CaCl}_{2}$. In the tests with this solution, high putity nitrogen gas ( $4 \mathrm{ppm} \mathrm{O}_{2}$ and $1.5 \mathrm{ppm} \mathrm{H}_{2} \mathrm{O}$ ) was bubbled to the cell at a nominal 4 cubic foot per hour. The solutions was renewed weekle.

The synthetic saliva ${ }^{[12]}$ was prepared with $0.25 \mathrm{~g} \cdot \mathrm{l}^{-1} \mathrm{~K}_{2} \mathrm{HPO}_{4} \cdot 3 \mathrm{H}_{2} \mathrm{O}, 0.30 \mathrm{~g} \cdot \mathrm{l}^{-1} \mathrm{NaH}_{2} \mathrm{PO}_{4}$, $1.50 \mathrm{~g} \cdot \mathrm{l}^{-1} \mathrm{NaHCO}_{3}, 0.7 \mathrm{~g} \cdot \mathrm{l}^{-1} \mathrm{NaCl}, 0.33 \mathrm{~g} \cdot \mathrm{l}^{-1}$ $\mathrm{KSCN}$ and $0.13 \mathrm{~g} \cdot \mathrm{l}^{-1}$ urea. Lactic acid was added to obtain $\mathrm{pH}$ 6.7. In the tests with this solution, air was bubbled using a pool fish pump. These solutions were renewed twice a week.

An ACM Instruments AutoAC was employed. All test were performed at free corrosion potential. Care had to be taken in order to avoid interferences in the signals, for example, those generated by triac responses and sudden changes of air or water pressure. The frequency ranges varied from 40000 to $0.0025 \mathrm{~Hz}$, fifteen logaritmic spaced readings, with $10 \mathrm{mV}$ of voltage amplitude. The interpretation of the impedance results was made by adjusting the data to a four capacitor-resistances model, connected in series with a solution resistance. The model was accepted when the coefficient correlation was 0.995 or greater.

\section{RESULTS AND DISCUSSION}

The EIS graphs obtained for mean immersion times of 5,11 and $24 \mathrm{~d}$ in both synthetic physiologic solutions of the three implant dental materials, appear in the figures 1 to 6 . 


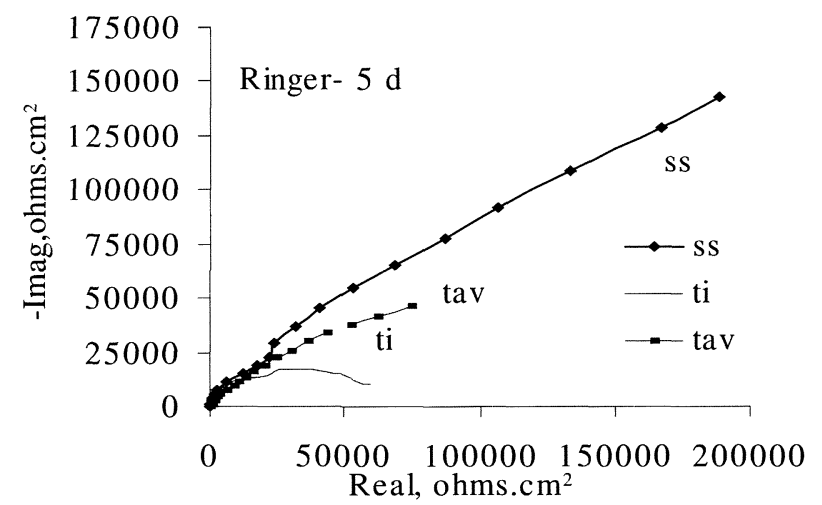

Figure 1. Nyquist plot in Ringer's solution - $5 \mathrm{~d}$.

Figura 1. Diagrama de Nyquist en solución de Ringer - $5 d$.

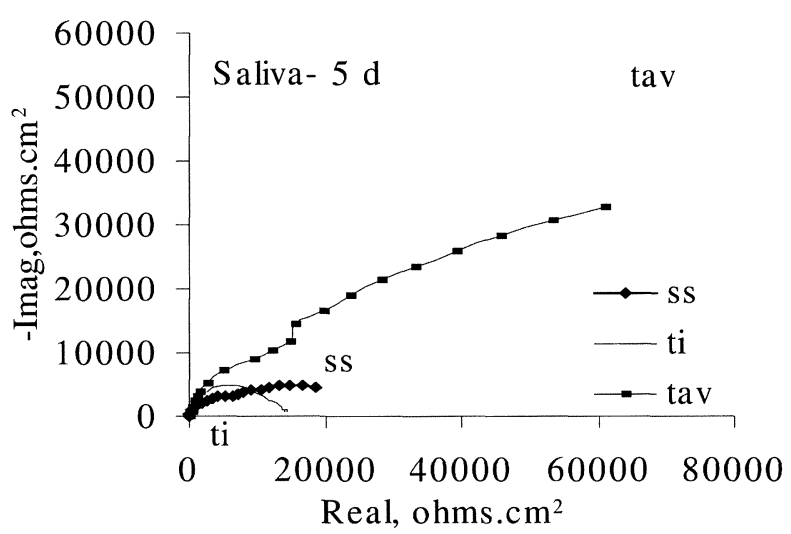

Figure 2. Nyquist plot in saliva solution - $5 \mathrm{~d}$.

Figura 2. Diagrama de Nyquist en solución de saliva - $5 d$.

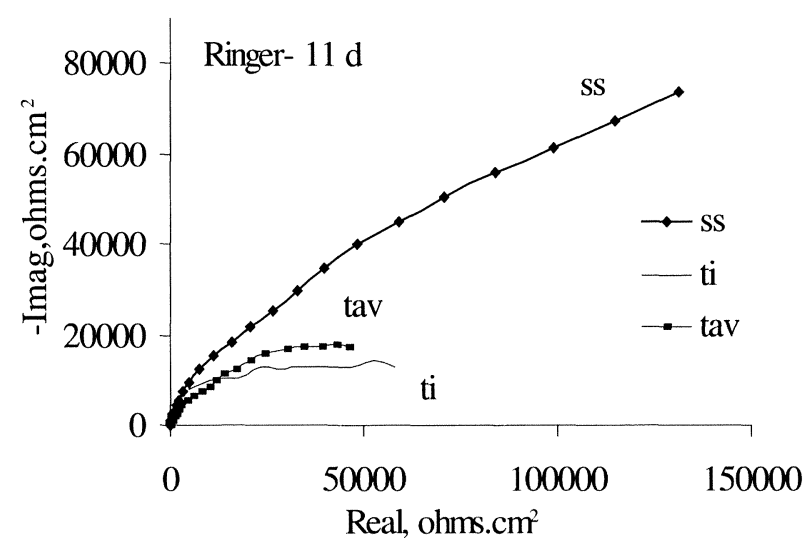

Figure 3. Nyquist plot in Ringer's solution - $11 \mathrm{~d}$.

Figura 3. Diagrama de Nyquist en solución de Ringer - $11 \mathrm{~d}$.

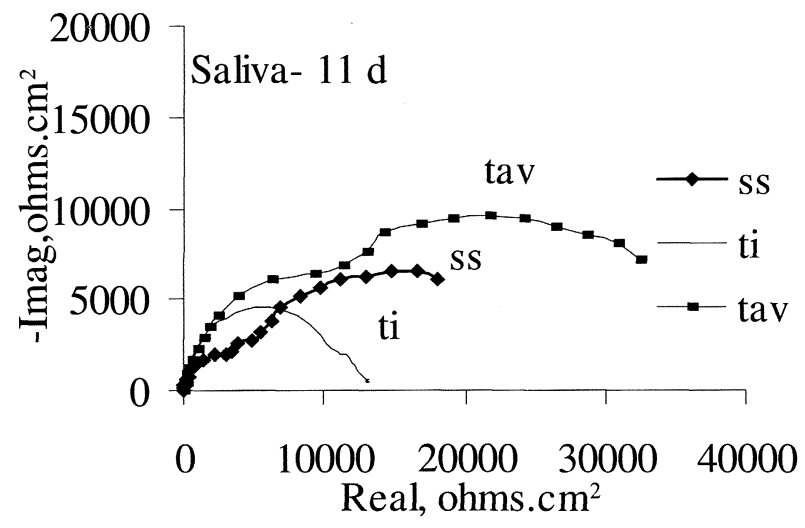

Figure 4. Nyquist plot in saliva solution - $11 \mathrm{~d}$.

Figura 4. Diagrama de Nyquist en solución de saliva - $11 \mathrm{~d}$.

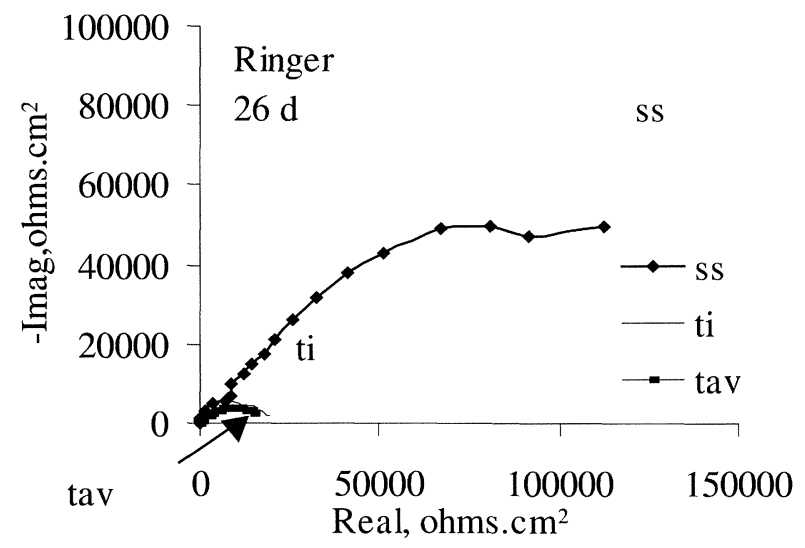

Figure 5. Nyquist plot in Ringer's solution - $26 \mathrm{~d}$.

Figura 5. Diagrama de Nyquist en solución de Ringer - $26 \mathrm{~d}$.

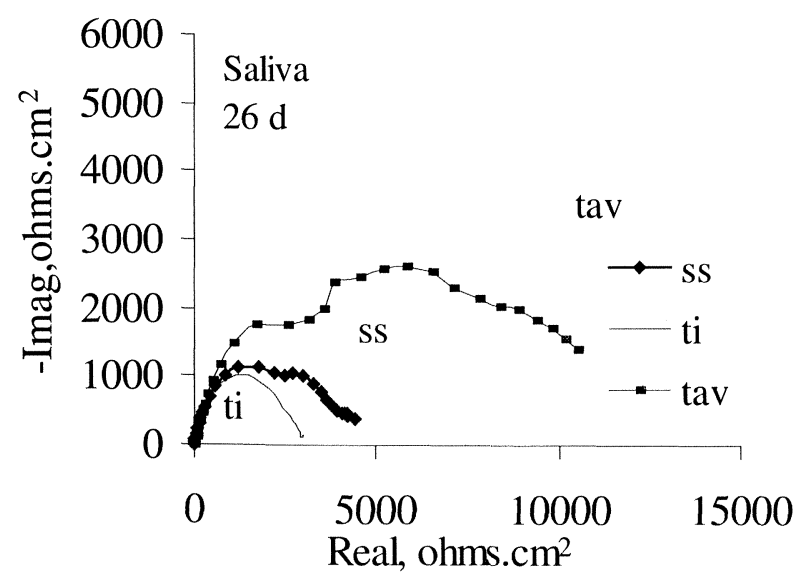

Figure 6. Nyquist plot in saliva solution - $26 \mathrm{~d}$.

Figura 6. Diagrama de Nyquist en solución de saliva - $26 d$. 
The above EIS results were simulated by an equivalent electrical circuit composed by four condensers and four resistance connected in series with the solution resistance. In these case, the impedance of the system are:

$$
Z=R_{s \text { ln }}+\frac{R_{1}}{j \omega C_{1} R_{1}+1}+\frac{R_{2}}{j \omega C_{2} R_{2}+1}+\frac{R_{3}}{j \omega C_{3} R_{3}+1}+\frac{R_{4}}{j \omega C_{4} R_{4}+1}
$$

The value of $R_{\text {sln }}$ was taken as $10 \mathrm{ohms} \cdot \mathrm{cm}^{2}$ in both solutions. The units of the capacitances of the condensers $C_{1}, C_{2}, C_{3}$ and $C_{4}$ are $\mu \mathrm{Fcm}^{-2}$ with the condition $\mathrm{C}_{1}<\mathrm{C}_{2}<\mathrm{C}_{3}<\mathrm{C}_{4}$. The units of resistances $R_{1}, R_{2}, R_{3}$ and $R_{4}$ are ohms $\cdot \mathrm{cm}^{2}$, with the subsequent restriction $C_{1} R_{1}<C_{2} R_{2}<C_{3} R_{3}<$ $\mathrm{C}_{4} \mathrm{R}_{4}$.

The Polarization Resistance was calculated by the equation

$$
R p=\operatorname{Lim}_{\omega \rightarrow 0} Z=R_{s \ln }+R_{1}+R_{2}+R_{3}+R_{4}
$$

All the data produced by the simulation of the three implants in the two synthetic physiological solutions are graphically shown in figures 7 to 12 . The first column in each figure is related to immersion times. The $2^{\text {nd }}$ to $5^{\text {th }}$ columns show the data for the capacitators $C_{1}$ to $C_{4}\left(\mu \mathrm{F} \cdot \mathrm{cm}^{-2}\right)$. Respectively, columns $6^{\text {th }}$ to $8^{\text {th }}$ show the values of the resistances associated to each condensers, $R_{1}$ to $R_{4}$ (ohms $\left.\cdot \mathrm{cm}^{2}\right)$ and the last column shows the polarization resistance, $\left(R p\right.$ in ohms $\left.\cdot \mathrm{cm}^{2}\right)$ deduced from the model.

The average correlation coefficients between the adjusted values deduced from the model to

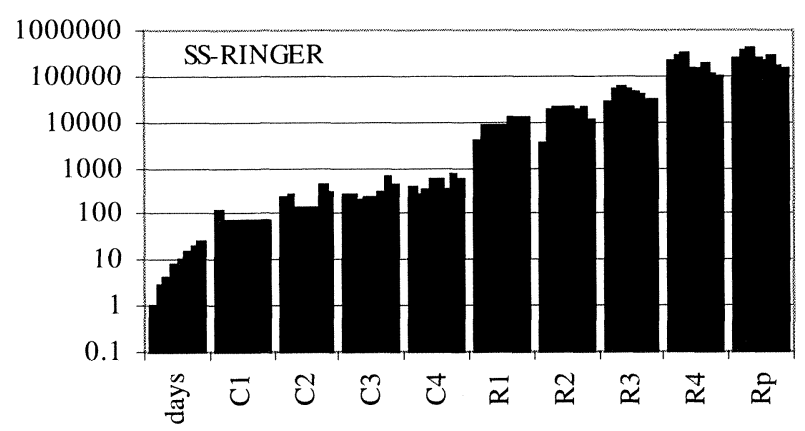

Figure 7. Values of the parameters deduced according to the time of inmersion ( $1^{\text {st }}$ columm) in the case of stainless steel in Ringer's solution.

Figura 7. Valores de los parámetros deducidos con el tiempo de inmersión (primera columna) en el caso del acero inoxidable en solución de Ringer.

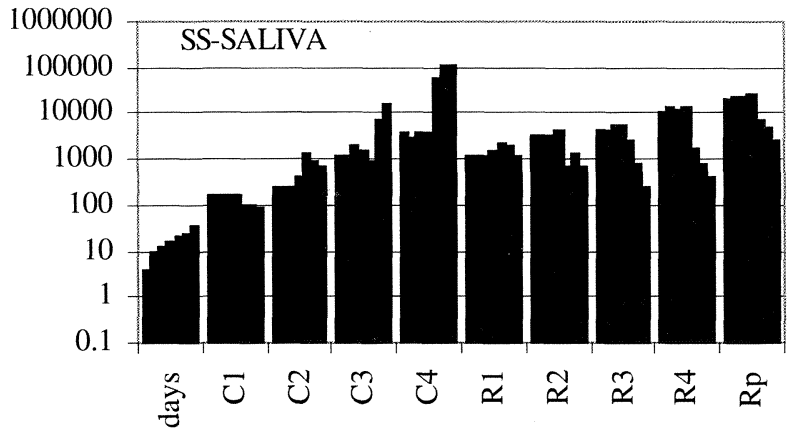

Figure 8. Values of the parameters deduced according to the time of inmersion ( $1^{\text {st }}$ column) in the case of stainless steel in saliva solution.

Figura 8. Valores de los parámetros deducidos con el tiempo de inmersión (primera columna) en el caso del acero inoxidable en solución de saliva.

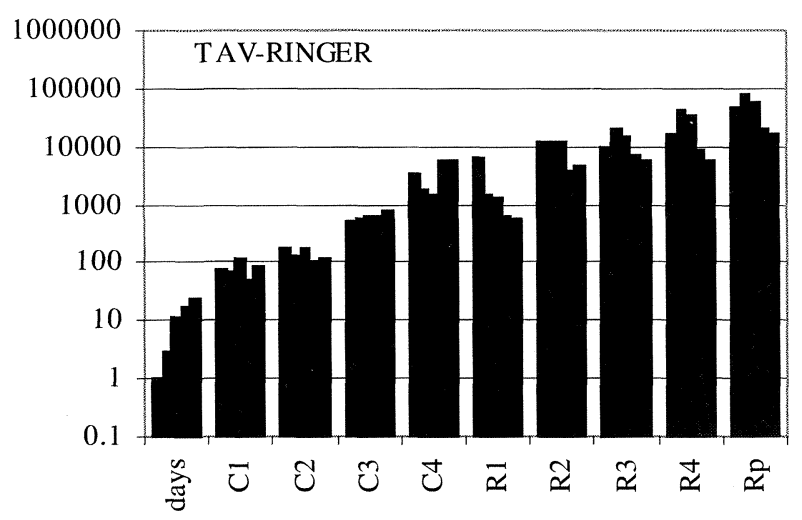

Figure 9. Values of the parameters deduced according to the time of inmersion ( $1^{\text {st }}$ column) in the case of $\mathrm{Ti} 6 \mathrm{Al} 4 \mathrm{~V}$ alloy in Ringer's solution.

Figura 9. Valores de los parámetros deducidos con el tiempo de inmersión (primera columna) en el caso de la aleación Ti 6Al 4V en solución de Ringer.

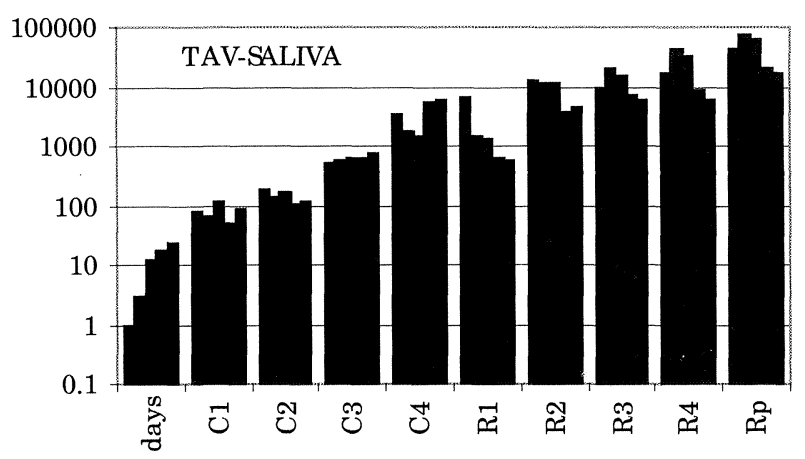

Figure 10. Values of the parameters deduced according to the time of inmersion ( $1^{\text {st }}$ column) in the case of $\mathrm{Ti} 6 \mathrm{Al} 4 \mathrm{~V}$ alloy in saliva solution.

Figura 10. Valores de los parámetros deducidos con el tiempo de inmersión (primera columna) en el caso de la aleación Ti 6Al 4V en solución de saliva. 


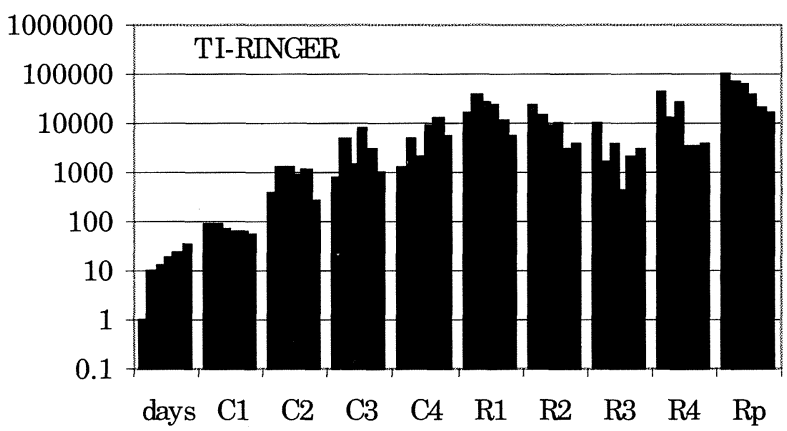

Figure 11. Values of the parameters deduced according to the time of inmersion $\left(1^{\text {st }}\right.$ column) in the case of titanium alloy in Ringer's solution.

Figura 11. Valores de los parámetros deducidos con el tiempo de inmersión (primera columna) en el caso del titanio en solución de Ringer.

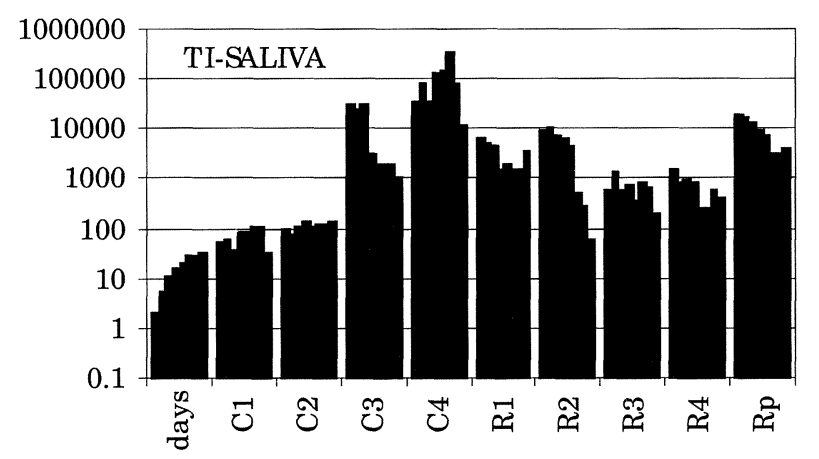

Figure 12. Values of the parameters deduced according to the time of inmersion ( $1^{\text {st }}$ column) in the case of titanium alloy in saliva solution.

Figura 12. Valores de los parámetros deducidos con el tiempo de inmersión (primera columna) en el caso del titanio en solución de saliva.

experimental data, taken as real part, imaginary part and impedance value, are respectively 0.998 , 0.993 and 0.998 .

The stainless steel shows better performance in the Ringer's media compared to the other alloys. In the saliva media the better performance was shown by the $\mathrm{Ti} 6 \mathrm{Al} 4 \mathrm{~V}$ alloy. The other two alloys show a similar behaviour in this media. In all tests the $R p$ is lower at greater immersion times.

The phenomenological model presented in this study, is based in three assumptions. First, each layer $(i=1,2,3,4)$ has its own capacitance $\left(C_{i}\right.$ in $\left.\mu \mathrm{F} \cdot \mathrm{cm}^{-2}\right)$ and resistance $\left(R_{i}\right.$ in ohms $\left.\cdot \mathrm{cm}^{2}\right)$ deduced from each simulation. Second, the layers are adjacent to one another in a "sandwich" system. Third, due to the restriction $\mathrm{C}_{1} R_{1}<$ $\mathrm{C}_{2} R_{2}<\mathrm{C}_{3} R_{3}<\mathrm{C}_{4} R_{4}$ imposed for the model, the relaxation times of the layers are in the relation $\tau_{1}<\tau_{2}<\tau_{3}<\tau_{4}$

If $A_{t}$ is the total surface area exposed to the physiological solution (in the present study, $0.03 \mathrm{~cm}^{2}$ ), then the capacitor and the resistance associated to the total area of the sample is:

$$
\begin{aligned}
& \mathrm{Ca}_{i}=\mathrm{C}_{i} \cdot \mathrm{At} \quad(\text { in } \mu \mathrm{F}) \\
& R a_{i}=\frac{R_{i}}{\mathrm{At}} \quad \text { (in ohms) }
\end{aligned}
$$

If $\varepsilon o$ is the permittivity in the vacuum $\left(=8.854 \times 10^{-12} \mathrm{~F} \cdot \mathrm{m}^{-1}\right)$ and $\varepsilon r_{i}$ is the dielectric constant of each layer, then the thickness of each layer can be roughly calculated as:

$$
L i=\frac{\varepsilon_{0} \cdot \varepsilon_{r i} \cdot A t}{C a_{i}}
$$

If the resistances associated to each layer are only due to the electrolyte that remains inside the pores, then the total area of pores is roughly:

$$
A p_{i}=\frac{L i \cdot \rho}{R a_{i}}
$$

where $\rho$ is the resistivity of the Ringer solution $(60 \mathrm{ohm} \cdot \mathrm{cm})$ or the saliva solution $(75 \mathrm{ohm} \cdot \mathrm{cm})$.

More accurately, the thickness of each layer can be calculated by further iteration as:

$$
L i^{*}=\frac{\varepsilon_{0} \cdot \varepsilon_{r i} \cdot\left(A t-A p_{i}\right)}{C a_{i}}
$$

where $L i^{*}$ is the calculated thickness after the first iteration.

Then, the new total area of the pores, after the first iteration is:

$$
A p_{i}^{*}=\frac{L i^{*} \cdot \rho}{R a_{i}}
$$

The process continues until minimum variations between two successive iterations are reached, then obtaining a desired degree of precision.

Graphically, the model is represented in the figure 13.

The proposed model implies that the pores between the layers are interconnected in order to secure that the relaxation times associated to the layers are only due to the discharges of the capacitors through the resistances associated to the 


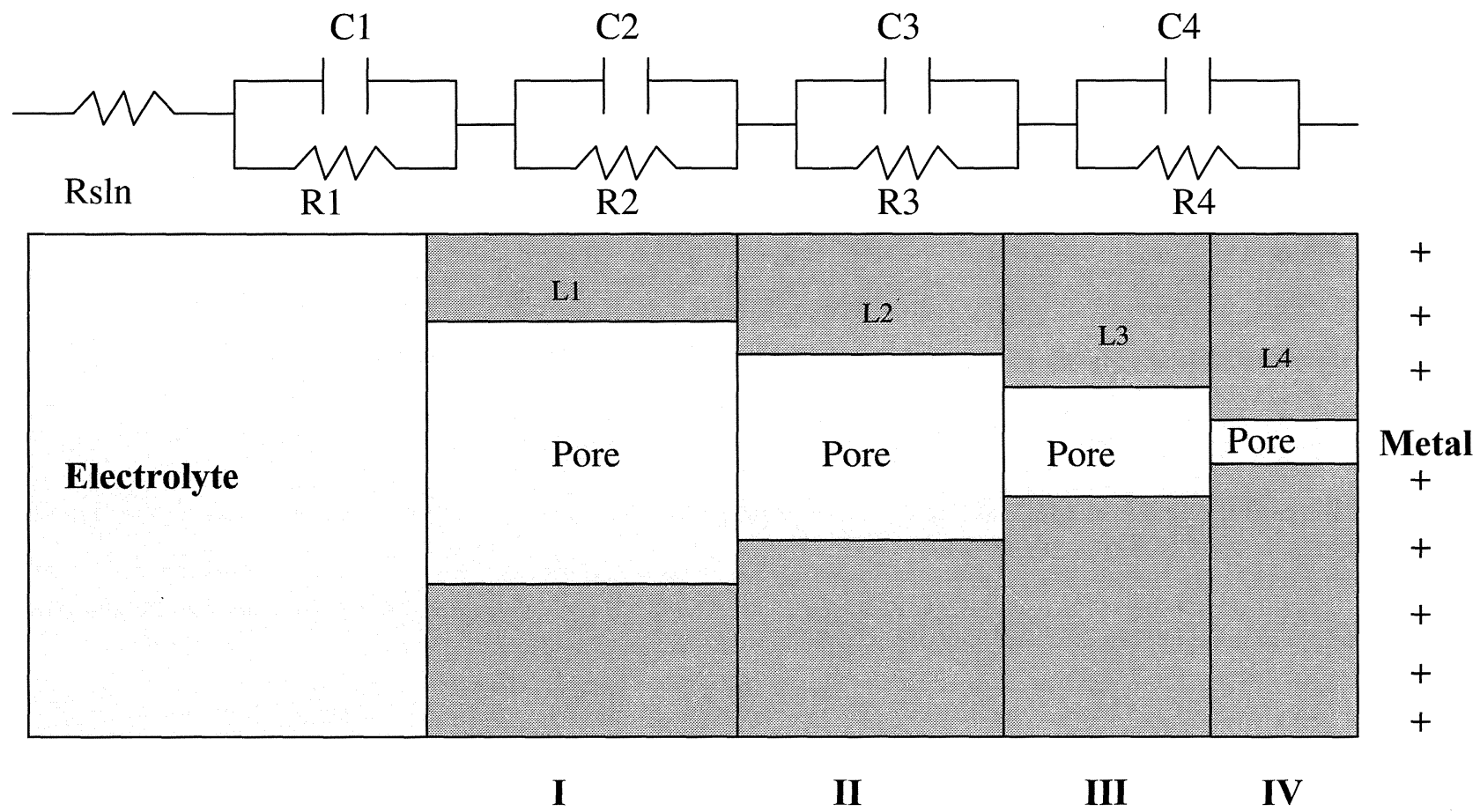

Figure 13. Equivalent electrical circuit used to simulate EIS results and proposed model of "sandwich" system of the layers of the implants in contact on the physiological solution. The pores of the layers are interconnected and filled with electrolyte solution.

Figura 13. Circuito eléctrico equivalente utilizado para la simulación de los resultados EIS (arriba) y modelo propuesto del sistema "sandwich" de las capas formadas en los implantes inmersos en la solución fisiológica. Los poros de las capas están interconectados y llenos del electrólito de la solución.

pores filled with the electrolytes and not through the resistances of layers himself (whose resistivities are usually $10^{10} \mathrm{ohm} \cdot \mathrm{cm}$ ). The interconnected pores are the path through the dissolution of the metal could take place.

Reported dielectric constants of some related materials include values ranging 80 to 160 for $\mathrm{TiO}_{2}[18$ and $20-21], 500$ for $\mathrm{PbTi}_{0.45} \mathrm{Zr}_{0.45} \mathrm{O}_{3}$ ceramic $^{[19]}$ and $1700^{[19]}$ or $4100^{[20]}$ for barium lead titanate; and values ranging from 50 to $10000^{[20]}$ or 10 to $8000^{[21]}$ for mixture of titanates. As a reference, a value of $\varepsilon_{r}=80$ for pure water ${ }^{[18]}$ falls in the range of the reported ones for the physiological solutions ${ }^{[19]}$.

As an example of application of the proposed model, the situation of the $\mathrm{Ti} 6 \mathrm{Al} 4 \mathrm{~V}$ alloy in the saliva solution after two days of immersion can be supposed. All the parameters deduced from the model are greatly influenced by the value of the dielectric constant employed. Assuming values in the range of 50 to 3000 , the thickness of the four layers varies in the range of 0.05 to $40 \mathrm{~nm}$ and the total area of interconnected pores varies in the ranges of 10 to $10^{5} \mathrm{~nm}^{2}$, as shown in the figures 14(a) and 14(b).
If $\varepsilon r_{1}=\varepsilon r_{2}=\varepsilon r_{3}=\varepsilon r_{4}=2000$, the evolution of the thickness of the layers $\left(\mathrm{L}_{1}\right.$ to $\mathrm{L}_{4}$ in $\mathrm{nm}$ ) and the total area of the interconnected pores $\left(A p_{1}\right.$ to $\mathrm{Ap}_{4}$, in $\mathrm{nm}^{2}$ ) for the Ti $6 \mathrm{Al} 4 \mathrm{~V}$ alloy, is graphically shown in figure $15(a)$ in saliva solution $(\rho=60 \mathrm{ohm} \cdot \mathrm{cm})$ and in the figure $15(\mathrm{~b})$ in Ringer's solution $(\rho=50 \mathrm{ohm} \cdot \mathrm{cm})$.

It is interesting to note that the thickness of the layers, deduced from the model tend to decrease with immersion time, in agreement with the increase of the capacitances of the layers, as depicted in figures 9 and 10. The total area of interconnected pores increases with time in agreement with the decrease of resistances associated to these layers. These results correspond to the observation of the decrease of the total impedance, or in other words, to the Polarization Resistance with respect to time.

Both trend shown in the figures 15(a) and 15 (b) are in agreement with the prediction that the resistance polarization of $\mathrm{Ti} 6 \mathrm{Al} 4 \mathrm{~V}$ in the Ringer and saliva solution are in the same order of magnitude (10000 to $\left.100000 \mathrm{ohms} \cdot \mathrm{cm}^{2}\right)$, as shown in figures 9 and 10. In addition to, the slight increase of $R p$ observed in the fist days of 


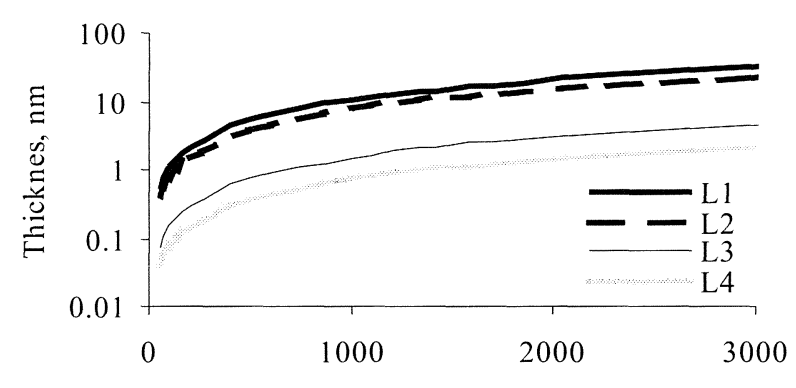

Dielectric constant

(a)

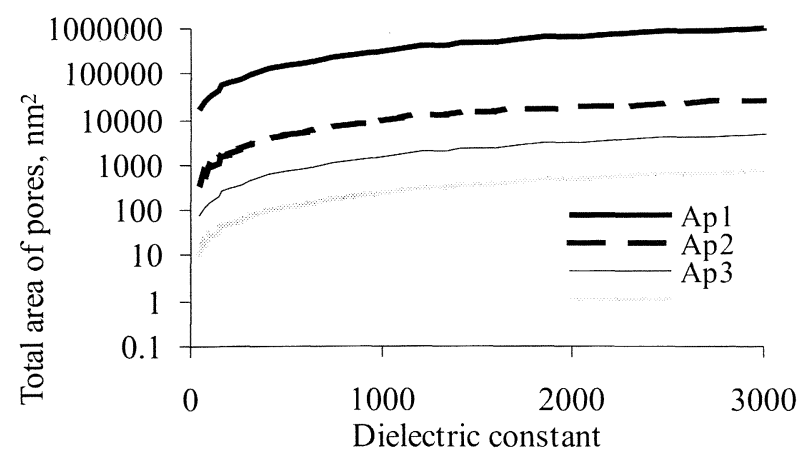

(b)

Figure 14. Thickening of the layers (a), and total area of pores (b) according to the dielectric constant value for the Ti 6Al $4 \mathrm{~V}$ alloy in saliva solution after 2 days of immersion.

Figura 14. Espesor de las capas (a) y área total de los poros (b) en función de la constante dieléctrica en el caso de la aleación Ti 6Al $4 \mathrm{~V}$ tras 2 días de inmersión en solución de saliva.

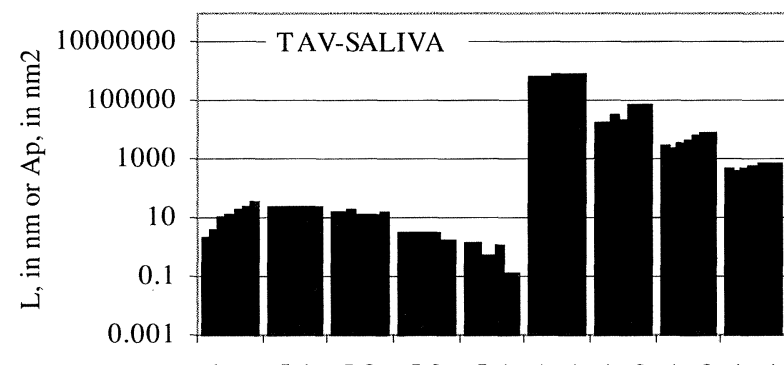

days L1 L2 L3 L4 Ap1 Ap2 Ap3 Ap4

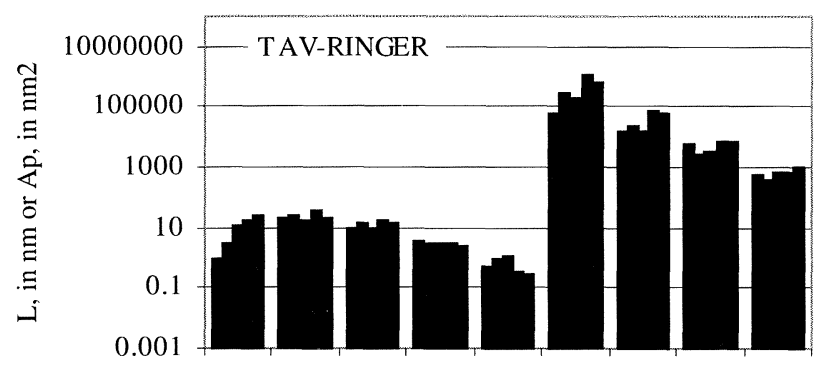

days L1 L2 L3 L4 Ap1 Ap2 Ap3 Ap4

(b)

Figure 15. Evolution of the thickness of the layers $\left(L_{1}\right.$ to $L_{4}$ in $\left.n m\right)$ and the total area of interconnected pores $\left(A p_{1}\right.$ to $A p_{4}$ in $\left.n m^{2}\right)$ according to the time of immersion for Ti $6 \mathrm{Al} 4 \mathrm{~V}$ alloy in saliva solution (a) and Ringer's solution (b). The resistivities of saliva and Ringer's solutions are respectively 60 and $50 \mathrm{ohm} \cdot \mathrm{cm}$.

Figura 15. Evolución del espesor de las capas ( $L_{1}$ a $L_{4}$ en $\mathrm{nm}$ ) y del área total de los poros interconectados $\left(A p_{1}\right.$ a $A p_{4}$ en $\left.n m^{2}\right)$ en función del tiempo de inmersión en el caso de la aleación Ti $6 \mathrm{Al} 4 \mathrm{~V}$ en la solución de saliva (a) y en la solución de Ringer. (b). Las resistividades de las soluciones de saliva y de Ringer son respectivamente 60 y $50 \mathrm{ohm} . \mathrm{cm}$.

immersion of $\mathrm{Ti} 6 \mathrm{Al} 4 \mathrm{~V}$ in both physiological solutions is correlated by a slight decrease of area of interconnected pores $\mathrm{Ap}_{2}, \mathrm{Ap}_{3}$ and $\mathrm{Ap}_{4}$.

This model explains the results of EIS in terms of layers developed in front of the surface of the metal. It is possible to correlate the outer layer (with parameters $C_{1}$ and $R_{1}$ - to the electrical double layer (with values around $100 \mu \mathrm{F} / \mathrm{cm}^{2}$ ) and the inner layer (with parameters $C_{4}$ and $R_{4}$ ), to the fourth layer. The intermediate layers are possibly related to the differential humectation of the most inner layer. Further efforts are neccesary in order to find the values of the dielectric constant of the passive layers, usually in the range of nanometers. In the case of the AISI 410 stainless steel, the passive layers have semiconducting characteristics $^{[22]}$ and it is possible that the dielectric constant differ from the reported values of "bulk" materials used in industrial ceramic capacitors $^{[18-20]}$.

It is important to point out that the results of this model are only qualitative and would be taken just as comparative measure of how different properties (porosity and thickness) of the layers changes with immersion times.

\section{CONCLUSIONS}

EIS results shows that the stainless steel display better performance in the Ringer's solution 
compared with to the other alloys. In the saliva media the better performance was shown by the $\mathrm{Ti}$ $6 \mathrm{Al} 4 \mathrm{~V}$ alloy. The stainless steel and commercially pure titanium shows a similar behaviour in this media.

The simulation of EIS results employing an equivalent circuit composed by four $\mathrm{RC}$ elements (one condenser in parallel with one resistance) in series with the solution resistance visualize the trend of the parameters (capacitances and resistances) with immersion time.

The phenomenological model presented in this study, is based in the assumptions that each element $\mathrm{RC}$ is correlated to a layer with a passing interconnected pore filled with the electrolyte solution and the layers are adyacent in a "sandwich" system. In addition, interconnected pores are the path through the dissolution of the metal could take place. This model could explain the results of EIS in terms of the evolution of the thickness of the layers and the total area of pores, according to the immersion time.

In particular, the observation of the decrease of the total impedance, or in other words, the polarization resistance with respect to time is correlated to the decrease of the thickness of the layers (in agreement with the increases of the capacitances) and the increase of the total area of interconnected pores in the layers (in agreement with decreases of resistances).

This results of this model should be taken only as cualitative measure of how the porosity and thickness of the layers change with immersion times, due to the high degree of uncertainty associated to the dielectric constant of the passive layers.

\section{REFERENCES}

[1] J. PARK and R. LAKES, Biomaterials. An Introduction, New York, $2^{\text {nd }}$ edition, 1992.

[2] A. Echavarría and J. Minotas, Cuad. Cerámicos Vítreos 8 (1999) 38.

[3] P. Kovaks, Symposium NACE, 1992, pp. 5-1 to 5-14.

[4] O. POHLER, ASM Hand., 11 (1994) 672-693.

[5] A. FraKer, Metals Handbook, $9^{\text {th }}$ Edition, 1993.

[6] H. AcCiari et al., Proc. $2^{\text {nd }}$ NACE Latin Amer. Region Corr. Cong., 1996. LA 96107.

[7] M. Cortizo and M. DE Mele, Proc. $2^{\text {nd }}$ NACE Latin Amer. Region Corr. Cong., 1996. LA 96149.

[8] Z. BAI, et al. Proc. $10^{\text {th }}$ Asia Pacific Corrosion Control Conf. Book, 1997. A25.1/5 to A25.5/5.

[9] L. JOSKA and P. NOVAK, Proc. 14 th Intern. Corrosion Congress, 1999. Paper No. 111 (2).

[10] M. Escudero, et al., Proc. $2^{\text {nd }}$ NACE Latin Amer. Region Corr. Congr., 1996. LA 96245.

[11] M. EsCudero, et al., Biomaterials. 169 (1995) 735.

[12] A. Echavarría and C. Arroyave, V Congreso Colombiano de Corrosión y Protección, 1999.

[13] C. Gabrielli and M. Keddam, Corrosion 4810 (1992) 794.

[14] F. Mansfeld, Electrochem. Acta. 3814 (1993) 1891.

[15] E. Angelini, et al., Proc. $14^{\text {th }}$ Intern. Corrosion Congress, 1999. Paper No. 11.1.

[16] M. Escunero, et al., Proc. $14^{\text {th }}$ Intern. Corrosion Congress, 1999. Paper No. 239.0.

[17] D. HAN and G. CHOI, Proc. $4^{\text {th }}$ Intern. Symp.on Electrochem. Imp. Spec., Brazil, 1999.

[18] E. Condon and H. Odishaw, Handbook of Physics. Mc Graw Hill, pp. 4-117.

[19] P. NeELAKANTA, Handbook of Electromagnetic Materials, CRC Press.

[20] D. Fink and J. Carroll, Standard Handbook of Electrical Engineers, 1994.

[21] A. KNOWLTON, Standdard Handbook for Electrical Engineers, 1967.

[22] S. ANGAPPAN and K. BALAKRISHNAN, $14^{\text {th }}$ Inter. Corrosion Congress, 1999, Paper No. 10.0. 